\title{
Foreign Direct Investment Flows and Fiscal Discipline in South Africa
}

\author{
N J Schoeman, Z Clausen Robinson and $\mathbf{T} \mathbf{J}$ de Wet
}

Department of Economics, University of Pretoria

\begin{abstract}
This paper investigates the impact of fiscal policy on foreign direct investment (FDI) in South Africa during the past 30 years. Casual empirical analysis reveals a definite linkage between FDI flows and variables such as the deficit/GDP ratio, representing fiscal discipline, and the tax burden on foreign investors. This relationship is substantiated by econometric analysis. Given the economy's large degree of dependence on foreign capital, the government may contribute to an investor-friendly environment by adjusting fiscal policy. Some inroads have been made in this regard with the government's Medium-term Expenditure Framework (MTEF), which projects a policy of strict fiscal discipline in years to come. However, the tax burden is still relatively high and, due to its impact on foreign direct capital flows, requires urgent attention.
\end{abstract}

JEL E62, F21

\section{INTRODUCTION}

The growing rate of global economic integration has a profound impact on economic policy - especially fiscal policy. Of particular importance in this regard, is the increase in trans-national capital mobility. According to pure economic theory, free capital flows improve global resource allocation and transfer of technology. However, it could also result in speculative runs on currencies, destabilising the macroeconomic framework and imposing adjustments on the fiscus, with detrimental consequences for the socio-economic environment. The events in Mexico (1994), South Africa (1996 and 1998), Thailand (1997) and Malaysia (1997), are illustrative of the excessive foreignexchange volatility that can arise from free international capital flows (Abedian, 1998: 21).

The liberalisation of international capital movements was precipitated by a major change in the perception of the role and scope of government in the economy during the last two decades (Guitián, 1999: 26). Government evolved 
from predominant participant in economic activity towards a situation in which government activity was designed mainly to provide an appropriate setting for private economic activity, which became the dominant force in resource allocation. Thus, strong markets developed in the international economy as a result of deliberate policy initiatives to liberalise capital movements. These in turn, tightened the links between national economies, with additional effects on fiscal and other policies.

\section{THEORIES EXPLAINING CAPITAL FLOWS}

The objective of this study is not so much to explain the theory behind capital flows, but to indicate how capital flows could be affected by fiscal policy. Therefore, a brief summary of existing theory on capital flows will suffice to illustrate this interrelationship.

According to Van der Walt (1994: 107), the debate on the determinants of foreign direct investment (FDI) in South Africa is characterised by misconceptions. Most of the arguments address only the factors that encourage or discourage FDI flows, instead of establishing a general framework for explaining FDI behaviour. Exchange controls, for example, frequently came under attack and it was claimed that FDI will increase when exchange controls are lifted. Others argued that a lack of political stability was the major deterrent for FDI for many years and that in the new, stable political dispensation, FDI will increase. Other arguments refer to the costly, unskilled and militant labour, relatively high domestic production costs, low productivity, protectionist industrial and trade policies, and the smallness of South Africa's domestic market compared to other emerging markets. Another argument, however, deserves special attention and forms the basis for this investigation. This argument concerns the impact of economic policies and, specifically fiscal policy, on FDI. Numerous studies of the emerging economies have identified fiscal discipline and a restricted, but efficient and unswerving economic role for government, as essential conditions for their economic success (Harmse, 1994: 38).

Amirahmadi (1994: 183) emphasises the importance of fiscal incentives to attract FDI. Such incentives include tax breaks and tax holidays, favourable utility usage fees, reduced custom duties and foreign exchange restrictions, relaxed ownership controls and streamlined administrative procedures. These are provided to foreign investors by host governments in an attempt to improve profitability and relax the strict control on the repatriation of profits. 
The newly industrialised countries (NICs) are typical of those countries whose host governments have utilised liberal and attractive incentives to sustain high levels of FDI inflows. Many countries also set up policy enclaves such as Export Processing Zones and Special Economic Zones, to promote foreign investment and export industries. Proven successes in this regard include the three zones in Taiwan and China's zones, which utilise close to 12 per cent of total FDI at the national level (lbid: 183).

However, Amirachmadi also cautions that the effectiveness of enclave zones as well as fiscal incentives in attracting FDI is limited. Multinationals (MNCs) invest according to their global strategy. If the investment climate in a developing country is generally unfavourable, the inducement offered by these zones is most unlikely to encourage MNCs to change their global development strategies.

Conventional economic theory has relied on a model of portfolio investment to explain the international movement of capital. This theory postulates interest rate differences among countries as the cause of international capital flows (Root, 1984: 456). Capital will flow from country A to country B when the long-term interest rate (return on capital) is higher in country B than in country $A$, reflecting the comparative abundance of capital in the latter. Capital will continue to flow from one country to the other until both interest rates and the marginal product of capital in the two countries are the same.

However, in South Africa, the data do not support the hypothesis that interest differentials explain the net flows of capital. This is also the case with FDI which, according to theory, will flow in when rates of return on FDI exceed the rates of return on home investment (Ibid: 456). This does not apply in South Africa, which foreign investors apparently still perceive as a high risk country. In fact, the majority of capital market transactions among residents of different countries, also in the South African case, could be identified as largely offsetting swaps of assets at market prices, i.e. portfolio arbitrage. The remainder of these gross flows constitutes real capital movements, i.e. trade of assets against goods.

A second hypothesis, namely that multinational enterprises expect to earn a higher income than local competitors, appears to offer a better explanation. The higher cost due to distance, time, information gaps, differences in nationality and culture, etc., must be off-set by incomes exceeding those earned by local competitors. The multinational enterprise earns a higher income through the advantages it gains over local competitors due to incentives, superior technology, entrepreneurial skills, etc., provided by the host country's government. 
It follows then, that the trends in foreign direct investment may be explained by departures from perfect competition (market imperfections). Three different forms of market imperfections are important in this regard, namely monopolistic practices, government induced externalities and country specific factors that influence the flow of foreign investment. In the latter case, fiscal policy and expectations regarding future fiscal policies, seem to be of fundamental importance. Not only has the ability of governments to tax capital diminished, tax competition has also led to a global reduction of profit taxes (Abedian, 1998: 24).

Tanzi (1996: 20) argues that globalisation increases the scope for tax competition', because it provides countries with an opportunity to export part of their tax burden to other countries. This opportunity clearly creates the possibility of abuse by some countries. Tax competition could, however, be advocated in order to counter the over-expansion of the public sector, which may result from other tax externalities and the pursuit of self-interest of bureaucrats and politicians. The lowering of, tax rates, i.e. capital income tax competition, void of harmful tax practices (OECD, 1998), could therefore be one of the disciplinary tools for future South African governments, assuming general financial stability (ceteris paribus).

The government's administration of public debt has become the focus point of fiscal policy evaluation by foreign as well as domestic investors. Countries with relatively high levels of deficit/GDP ratios are under great pressure to undergo fiscal adjustment policies. In view of the uncertainty regarding capital flows caused by the above-mentioned externalities, it is believed that fiscal surpluses serve as a buffer to minimise disruption in the delivery of public goods and services (Ibid: 25).

\section{TAX SENSITIVITY OF FOREIGN DIRECT INVESTMENT}

For countries where the degree of FDI penetration is high, the revenue raised from taxing FDI can represent a significant portion of total tax revenues. However, should the volume of FDI respond negatively to taxation, the host country must trade off the revenue gains (if any) of increased taxation against the economic cost of discouraging FDI. In a study by Shah and Slemrod (1990: 2), it was found that in the case of Mexico, FDI was very sensitive to changes in domestic tax rates relative to those of investing countries. However, the authors also pointed out that, in addition to taxation, the regulatory framework and overall economic and political climate in Mexico have a substantial impact on FDI transfers and reinvestments. 
Modern literature has, for the most part, concluded that the demand for FDI is primarily an issue of industrial organisation (Shah, 1990: 15). The effective tax rate on corporate income from FDI is a complex function of the statutory tax rate on corporate income, the extent of tax credits granted and the definition of the tax base, including the system of depreciation and how gross income and deductions are allocated between countries.

According to Shah (Ibid: 16), there are two approaches to measure the impact of the effective tax rate on new investment. According to the analytical approach, the level of pre-tax return required for a stylised investment to yield a given return after tax, is calculated. The magnitude of the difference between the pretax rate of return and the after tax rate is a measure of the tax-related disincentive to invest. The other approach would be to calculate the ratio of taxes paid in a given year, by means of some measure of income that is independent of the definition of taxable income. This approach may capture some of the features of the tax law and other factors (such as inflation), which are not accommodated by the analytical approach.

Another factor that would impact on the effective tax rate, is whether the tax is levied according to the territorial or world-wide system. Under a territorial system, the home country levies no tax of its own on the foreign source income. Under the world-wide system, the multinationals' home country asserts the right to tax its income regardless of where it is generated. In order to avoid two tiers of taxation, these countries offer their multinationals a limited credit against domestic tax liability for certain taxes paid to foreign governments. In most cases the tax liability (and credit) attendant to subsidiaries' foreign-source income is deferred until dividends are repatriated to the parent company.

\section{CAPITAL FLOWS TO AND FROM SOUTH AFRICA - AN EMPIRICAL ANALYSIS}

The South African economy is characterised by a severely sub-optimal performance (SARB: S-147). Due to the low level of average growth, unemployment is a major problem. Furthermore, the data also indicate so-called jobless growth. This low level of growth impacts negatively on savings, which in turn impede growth as a result of a lack of foreign capital to finance the required level of investment that would cure the unemployment problem.

Figure 1 shows that net capital flows to South Africa became very volatile since the mid-seventies, after political incidents such as the Sharpeville uprising in 1976. The volatility (and negative tendency in net capital flows) became even more evident after 1984, which will be remembered for the so-called "Rubicon" 
speech of the then prime minister, Mr P W Botha. This had a very negative impact on investment and, therefore, economic growth and job creation in South Africa, especially in view of the very low savings propensity of South Africans. Government savings in particular, but also personal savings performed very poorly. The saving/GDP ratio reached a maximum of 35 per cent in 1981, whereafter it declined to below 15 per cent in 1998 (SARB: S-130). During the same period, the investment/GDP ratio declined from 33 per cent to approximately 16 per cent. Thus, the country is to a large extent dependent on foreign capital, not only to bridge the current gap between savings and investment, but also to expand investment to more acceptable levels.

Table 1 also shows that most of the foreign capital that is being invested in South Africa, is in the form of portfolio investment that could be withdrawn in the very short run. A large amount of investment in South African equities also seems to be from index traders, investors who purchase a basket of equities of different countries, according to their share in the International Finance Corporation (IFC) emerging market index. South Africa's ability to attract FDI is, therefore, tested continuously.

\section{Figure 1 Net Capital Flow and FDI}

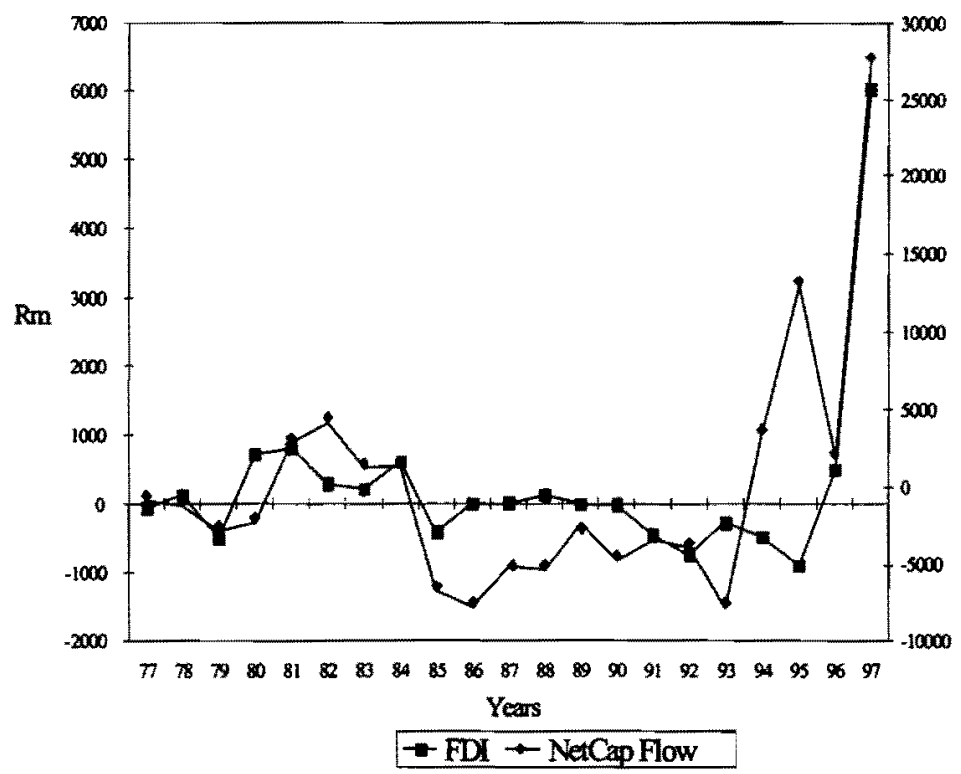


Table 1: Direct and Portfolio Investment in South Africa

\begin{tabular}{|c|c|c|}
\hline Year & Direct Investment & Portfolio investment \\
\hline 1991 & 111 & 666 \\
\hline 1992 & -5514 & 4950 \\
\hline 1993 & 941 & 2417 \\
\hline 1994 & -3040 & 10008 \\
\hline 1995 & -4557 & 9020 \\
\hline 1996 & -970 & 9576 \\
\hline 1997 & 6756 & 30580 \\
\hline 1998 & -6471 & 20375 \\
\hline
\end{tabular}

Source: S A Reserve Bank, December 1999

Next, the changes in tax policy that could impact on tendencies in FDI had to be analysed. Various tax law amendments are proof of government's commitment to fiscal reform. Since 1994, Non-resident Shareholders' Tax has been abolished, the corporate tax rate has been lowered to 35 per cent in 1990 , and to 30 per cent in 1999. Further amendments included the extension of the source provisions to tax residents on their passive income from a foreign source, as well as the incorporation of transfer pricing and the capitalisation provisions in the Income Tax Act (Katz, 1994 and 1995). Apart from this, the South African government introduced various supply side measures as part of its macroeconomic strategy for growth, redistribution and employment (GEAR). Major elements of this policy include:

(a) an accelerated depreciation allowance for income tax purposes on plant and equipment and on buildings intended for manufacturing activities, as from 1 July 1996; and

(b) a tax holiday of up to 6 years for new projects with assets in excess of R3 million.

\section{THE MODEL}

The discussion thus far suggests that a general empirical model explaining the impact of fiscal discipline on FDI could have the following form:

$$
F D I_{s}=f\left(y, R,\left(t_{v}-t\right), x, d\right)
$$

where $\mathrm{x}$ is the deficit/GDP ratio which represents the state of fiscal discipline. $\mathrm{R}$ is a risk index for investing countries. The risk index consists of three components, each with a weight of 33 per cent. These components consist of 
the foreign debt/GDP ratio, interest payments/ export earnings; and the extent of import cover. The parameter $d$ represents a dummy variable to correct the impact of sanctions, and y represents a yield-interest differential. The parameter $t$ represents the effective rate of taxation on new investment by the recipient country and $t$ is the tax rate of the home country. The data used in the estimation were obtained from the South African Reserve Bank, the International Financial Statistics, Government Statistics and the World Bank. The time series covers the period 1970 to the end of 1998.

To determine the influence of the tax rate on foreign direct investment in South Africa, the absolute value of corporate tax in South Africa and the United Kingdom is expressed as a ratio to the respective countries' GDP, with a series consisting of the differential between the two ratios. In both cases, taxes as well as GDP values are expressed in terms of United States dollars.

In order to capture the effect of the yield (return) on investment in South Africa, the net operating surplus is expressed as a percentage of total fixed investment in South Africa. For investment to be profitable, the yield on investment should exceed its opportunity cost. Therefore, the real interest rate in South Africa was deducted from the yield on investment.

The equation was estimated using the Engel and Yoo three step approach. The long-run equilibrium equation was followed by the estimation of an error correction model (ECM) to capture the short run effects. The last step in the Engel and Yoo approach uses the ECM to estimate the final long-run equilibrium equation. The functions are based on similar work done by Shah and Slemrod, 1990: 20). The long-run results are reported below.

\section{ESTIMATION OF THE ENGEL AND YOO LONG-RUN EQUATION}

The estimated long-run model and the calculated t-values are summarised in Table 2.

The results in the above table represent the final long-run cointegration equation for foreign direct investment in South Africa. Economic evaluation of this relationship indicates that all the variables have the expected sign. In addition, all the variables are statistically significant at the 5 per cent level of significance. 
Table 2: Engle and Yoo long-run equation

Dependent variable: Foreign direct investment/GDP

\begin{tabular}{|l|c|c|c|}
\hline Explanatory variable: & Coefficient & Standard Error & t-ratio \\
\hline $\begin{array}{l}\text { South African } \\
\text { Government Deficit/GDP }\end{array}$ & -137395.93 & 34476.10 & $-3.98^{*}$ \\
\hline Corporate tax differential & -74.89 & 37.78927 & $-1.98^{*}$ \\
\hline Yield-Interest differential & 0.000917 & $3.15 \mathrm{E}-05$ & $2.66^{*}$ \\
\hline Risk index & -0.000138 & $2.85 \mathrm{E}-05$ & $-4.85^{*}$ \\
\hline Sanctions dummy & -0.005832 & 0.001666 & -3.51 \\
\hline
\end{tabular}

Significant at the 5 per cent level of significance.

The significance of the results in Table 2 is that both the fiscal policy variables have an effect on foreign direct investment. More specifically, an increase in the difference between the South African corporate tax level (expressed as a ratio to the South African GDP), and the United Kingdom corporate tax level (also as a ratio to the United Kingdom GDP), reduces foreign direct investment relative to the GDP in South Africa. The effect of changes in the budget deficit before borrowing relative to the GDP, has an even greater negative impact on foreign direct investment relative to the South African GDP. Furthermore, an increase in the difference between the return on investment and the interest rate also proved to be significant for FDI flows. The risk index and the effect of sanctions also proved to be statistically significant.

\section{CONCLUSION}

Fiscal policy is gaining in importance in growth-oriented adjustment programs supported by the necessary inflow of capital. Not only should it contribute to increased domestic saving to finance the required level of investment, but due account should also be taken of the way in which fiscal policy influences the net flow of foreign direct investment. For South Africa, to successfully address its development problems, substantially more FDI has to be attracted. The empirical results from this study show that a lot will have to be done to transform the South African economy into an investor friendly environment. Apart from pure economic reasons based on market principles, government policy (especially also fiscal policy), plays a major role in this regard. Of special importance are the deficit before borrowing and the relative tax burden on prospective investors in South Africa.

The increase in both the tax burden and the deficit/GDP ratios during the eighties and beginning of the nineties, have impacted negatively on FDI and, therefore, on economic growth in the country. Serious attention should be paid 
to the relationship between the structure of taxation and its impact on foreign direct investment. In South Africa, a heavy dependence on a few tax instruments, applied at high rates to a limited number of taxpayers, has resulted in severe distortions in relative prices, providing incorrect signals to investors. The LTEF (Long Term Expenditure Framework) of the government, has made some progress towards solving this problem.

\section{ENDNOTE}

I Various measures can be taken by governments (national as well as subnational level), to adjust (lower) their tax rates in order to attract mobile factors of production (capital is seen as the most mobile factor of production) from other regions. Tax competition can, therefore, also be regarded as an inter-jurisdictional externality and can lead to an inadequate supply of public services.

\section{REFERENCES}

1 ABEDIAN, I. and BIGGS, M. (1998) Economic Globalisation and Fiscal Policy, Oxford University Press, Cape Town.

2 AMIRACHMADI, H. and WU, W. (1994) "Foreign Direct Investment in Developing Countries", Journal of Developing Areas, 28, part 2.

3 DEPARTMENT OF FINANCE (1999) Budget Review.

4 HELLER, P.S. (1997) "Fiscal Policy Management in an Open Capital Regime", IMF Working Papers, WP 97/20.

5 IMF RESEARCH DEPARTMENT STAFF (1997) "Capital Flow Sustainability and Speculative Currency Attacks", Finance and Development, December.

6 MAHLER, W. (1990) "The Growth of the Korean Capital Market", Finance and Development, June.

7 RAZIN, A. and YUEN, C. (1996) "Capital Income Taxation and LongRun Growth: New Perspectives", Journal of Public Economics, 59.

8 ROOT, F.R. (1984) International Trade and Investment $\left(5^{\text {th }}\right.$ ed.) SouthWestern Publishing $\mathrm{Co}$, University of Pennsylvania.

9 SHAH, A. and SLEMROD, J. (1990) "Tax Sensitivity of Foreign Direct Investment: An Empirical Assessment", Policy Research and External Affairs, Working Papers, World Bank.

10 SOUTH AFRICAN RESERVE BANK, Quarterly Bulletin of the Reserve Bank, various issues.

11 VAN DER WALT, J. and DE WET, G.L. (1994) "The Prospects for Foreign Investment in South Africa", Strategic Review for Southern Africa, vol. 16(2). 